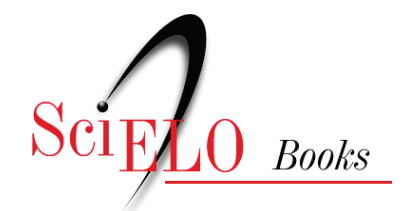

\title{
Metabolismo social da cidade e outros ensaios
}

\author{
Ruben George Oliven
}

OLIVEN, RG. Metabolismo social da cidade e outros ensaios [online]. Rio de Janeiro: Centro Edelstein de Pesquisas Sociais, 2009. 51 p. ISBN: 978-85-7982-012-0. Available from SciELO Books $<$ http://books.scielo.org $>$.

\section{(1) (1) (2)}

All the contents of this chapter, except where otherwise noted, is licensed under a Creative Commons Attribution-Non Commercial-ShareAlike 3.0 Unported.

Todo o conteúdo deste capítulo, exceto quando houver ressalva, é publicado sob a licença Creative Commons Atribuição Uso Não Comercial - Partilha nos Mesmos Termos 3.0 Não adaptada.

Todo el contenido de este capítulo, excepto donde se indique lo contrario, está bajo licencia de la licencia Creative Commons Reconocimento-NoComercial-CompartirIgual 3.0 Unported. 
Ruben George Oliven

\section{Metabolismo Social da Cidade e Outros Ensaios}


Esta publicação é parte da Biblioteca Virtual de Ciências Humanas do Centro Edelstein de Pesquisas Sociais - www.bvce.org

Copyright (c) 2009, Ruben George Oliven

Copyright (c) 2009 desta edição on-line: Centro Edelstein de Pesquisas Sociais

Ano da última edição: 1974

Nenhuma parte desta publicação pode ser reproduzida ou transmitida por qualquer meio de comunicação para uso comercial sem a permissão escrita dos proprietários dos direitos autorais. A publicação ou partes dela podem ser reproduzidas para propósito não-comercial na medida em que a origem da publicação, assim como seus autores, seja reconhecida.

Para Arabela

Para Paulo Martins Machado

ISBN 978-85-7982-012-0

Centro Edelstein de Pesquisas Sociais

www.centroedelstein.org.br

Rua Visconde de Pirajá, 330/1205

Ipanema - Rio de Janeiro - RJ

CEP: 22410-000. Brasil

Contato: bvce@centroedelstein.org.br 


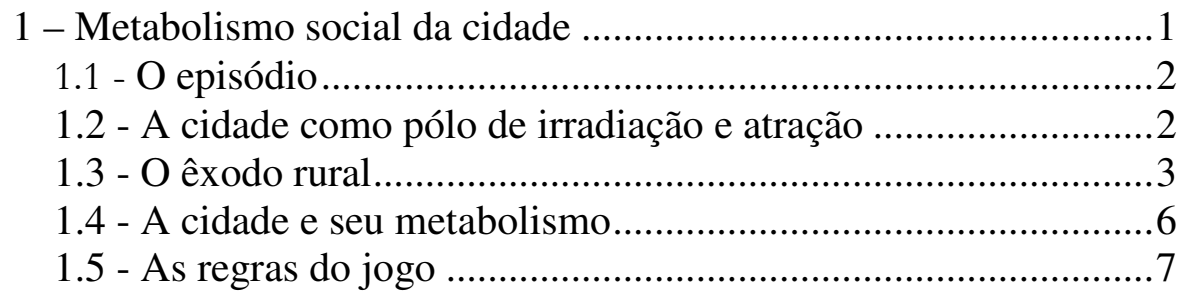

2 - Progresso, felicidade \& Cia. Ltda.

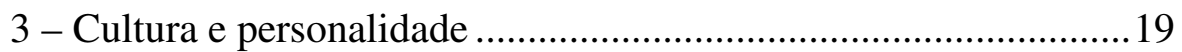

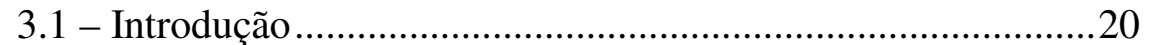

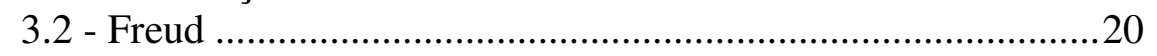

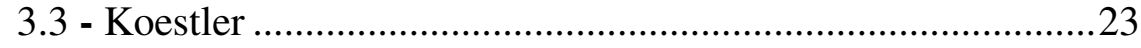

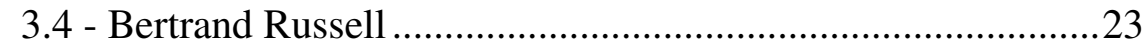

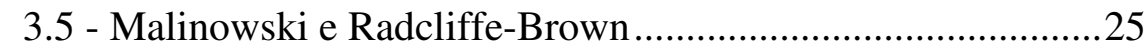

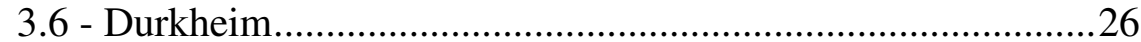

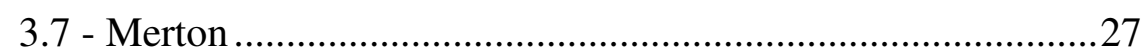

3.8 - Estudos psicológicos e culturalistas …………….....................31

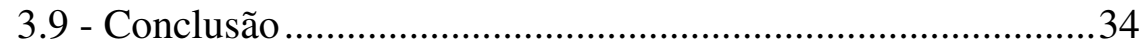

4-O mito de Abel e Caim e o surgimento da cidade bíblica ............38 4.1 - $\mathrm{O}$ aspecto histórico-social .......................................................40

4.2 - A análise do mito ................................................................ 41

5 - América Latina: educação e desenvolvimento...............................46

\section{1 - METABOLISMO SOCIAL DA CIDADE}


1.1 - O episódio

Em 1964, no calmo bairro residencial de Queens, em New York, uma moça de 28 anos, Catherine Genovese, foi morta a punhaladas por um louco homicida. $\mathrm{O}$ fato ocorreu aproximadamente às três horas da manhã e 38 pessoas assistiram, por trás das janelas de seus lares, ao crime, que durou trinta minutos. Ninguém fez qualquer coisa para impedir a morte de Catherine, que estava a apenas trinta metros da porta de sua casa quando recebeu a última punhalada.

Nenhuma das testemunhas do crime tomou qualquer atitude para evitá-lo. Se alguém tivesse telefonado à polícia, esta poderia estar no local em poucos minutos. Entretanto, a polícia recebeu um primeiro telefonema depois de Catherine ter morrido.

Como explicar este acontecimento que teve repercussão mundial e inspirou algumas peças teatrais?

\section{2 - A cidade como pólo de irradiação e atração}

A cidade funciona como um pólo de irradiação e de atração em relação ao campo e às cidades menores. À primeira vista a força deste pólo é diretamente proporcional a seu tamanho. Entretanto, o poder de irradiação e atração de uma cidade não é fruto exclusivo do número de seus habitantes, mas também da concentração de equipamentos e de atividades e da vida social nela existente.

Um bom indicador desta força é o grau informativo das cidades. Richard Meier (1962) estima que nas grandes metrópoles cada cidadão receba 100 milhões de informações por ano, ou seja, cem vezes mais do que ocorre na média das cidades menos desenvolvidas.

A cidade transmite uma série de mensagens que chegam ao campo e cidades menores, lá exercendo um forte fascínio. Ela é vista como um lugar onde é possível ascender social e economicamente, onde os rígidos controles sociais do meio rural inexistem e onde é possível dar vazão às aptidões e vocações individuais.

A cidade realmente oferece maior número de oportunidades individuais. $\mathrm{O}$ número de comportamentos alternativos é muito maior que no campo ou nas pequenas cidades, onde as excentricidades não são tão facilmente aceitas.

Na cidade é possível viver num doce anonimato sem o controle que se verifica no campo. O elemento vergonha - muito forte no meio rural - é bem mais tênue na cidade, onde os comportamentos considerados excêntricos no campo são tolerados e no qual as peculiaridades individuais são diluídas e aceitas.

A cidade funciona, sob este aspecto, como um cadinho que tolera e reforça as diferenças individuais.

A situação da cidade como um pólo de irradiação e atração acentua-se cada vez mais com a grande utilização dos meios de comunicação de massa. Forma-se uma pressão dos valores urbanos que não encontram possibilidade de realização no meio rural. A cidade invade o campo (e as cidades menores) bombardeando-o de mensagens e estende sua atração até ele.

\section{3 - O êxodo rural}

Visando a maiores oportunidades sociais, econômicas ou culturais, as pessoas abandonam o campo e dirigem-se à cidade. Para esta, trazem seus antigos hábitos e padrões que nela persistem. A própria maneira de perceber a nova realidade é feita com os antigos padrões.

O ajustamento à cidade vem acompanhado de dificuldades características das fases de transição e, até que ocorra a aceitação e integração de novos padrões e valores, é frequentemente caracterizado por um processo de anomia pessoal e social.

Anomia (pessoal), segundo MacIver, significa "o estado de espírito de alguém que foi arrancado de suas raízes morais, que já não segue quaisquer padrões mas somente necessidades avulsas, que já não tem qualquer senso de continuidade, de grupo e de obrigação. $\mathrm{O}$ homem anônimo tornou-se espiritualmente estéril, reage somente diante de si mesmo, não é responsável para com ninguém. Ele ri dos valores de outros homens. Sua única fé é a filosofia da negação. Vive 
sobre a débil linha da sensação entre nenhum futuro e nenhum passado. A anomia é um estado de espírito no qual o senso de coesão social - mola principal da moral - está quebrado ou fatalmente esquecido?"”.

Merton afirma que a anomia (social) é "concebida como uma ruptura na estrutura cultural, ocorrendo, particularmente, quando há uma disjunção aguda entre as normas e metas culturais e as capacidades socialmente estruturadas dos membros do grupo em agir de acordo com os primeiros. Conforme esta concepção, os valores culturais podem ajudar a produzir um comportamento que esteja em oposição aos mandatos dos próprios valores"b

Disto pode-se inferir que existe não somente uma marginalidade econômica ocasionada pela incapacidade do sistema econômico absorver o contingente formado pelo êxodo rural, mas também uma marginalidade psicossocial decorrente da dificuldade de entender a cidade e de assimilar seus valores.

Uma das principais características do meio rural é a sensação de pertencer a algo. No campo, o indivíduo, qualquer que seja sua posição social, tem nítida consciência de fazer parte de grupos. A família é um grupo sólido, a vizinhança também o é. Igualmente, a posição individual dentro da comunidade é bem definida. As relações individuais baseiam-se predominantemente em contatos primários e diretos.

A cidade como pólo de atração é vista como um sistema inclusivo. E é justamente sua inclusividade que funciona como força de atração. $\mathrm{O}$ indivíduo que consegue chegar à perimetria deste sistema quer estar nele incluído.

A cidade, entretanto faz com que os antigos vínculos do indivíduo sejam enfraquecidos ou rompidos sem oferecer uma alternativa que compense imediatamente esta perda.

Com o êxodo rural, a família grupo primário por excelência é acentuadamente modificada. Ela deixa de ser extensa e torna-se

${ }^{a}$ MERTON, Robert K. Sociologia, Teoria e Estrutura. São Paulo, Mestre Jou, 1970. P.236. b Ibid. nuclear. A autoridade paterna é consideravelmente diminuída, quando não entra em falência como entidade tal como é concebida no campo. Neste, a família é uma célula de produção e de consumo, enquanto na cidade ela não desempenha nenhum destes dois papéis, pois cada membro trabalha noutro local e o consumo de refeições, por exemplo, frequentemente é feito perto do local de trabalho.

Os grupos aos quais o indivíduo se filia são divergentes, pois cada um deles atende a uma necessidade ou interesse específico, envolvendo apenas um aspecto de sua personalidade e contribuindo, por conseguinte, para sua fragmentação e marginalidade psicossocial.

Nas comunidades rurais ou nas sociedades menos diferenciadas, os grupos aos quais o indivíduo deve fidelidade obedecem a uma ordenação hierárquica. Como, na cidade, "os grupos aos quais a pessoa está tipicamente filiada são tangenciais uns aos outros ou se entrecortam de forma altamente variada e nenhum grupo isolado é possuidor de fidelidade exclusiva do indivíduo"c, este fica desorientado, sem saber a que grupo pertence integralmente.

Esta desorientação nada mais é do que a dificuldade de perceber e compreender a nova estrutura na qual está vivendo. E como a principal característica desta estrutura (a cidade) é o seu rápido ritmo de auto-transformação, torna-se impossível captá-la no seu sentido estático. São os antigos padrões de percepção que impossibilitam ao indivíduo perceber a nova realidade dinâmica.

A estrutura social também é menos rígida e mais complexa no meio urbano, possibilitando ao cidadão um status mais flutuante que no campo. Sua vida social envolve uma grande variedade de tipos de indivíduos com os quais se depara nos grupos sociais diferenciados que compõem a estrutura social na cidade. Por isto, o cidadão "tende para a aceitação da instabilidade e insegurança no mundo como norma geral. Esse fato contribui, também, para a sofisticação e o cosmopolitismo do habitante da cidade"d.

c WIRTH, Louis. "O Urbanismo como modo de vida". In VELHO, O . G. O Fenômeno Urbano. Rio de Janeiro, Zahar, 1967. P.113)

d Ibid 
Torna-se claro porque as cidades, principalmente as grandes cidades, encontram-se em equilíbrio instável.

\section{4 - A cidade e seu metabolismo}

Chama-se de metabolismo social da cidade sua capacidade de moldar o caráter da vida social a sua forma especificamente urbana. Isto implica em saber qual é o grau de integração do indivíduo na cidade.

Vimos que a cidade tende a substituir os contatos e o relacionamento subjetivos por um padrão baseado na objetividade e no interesse específico. Isto alivia a pressão, o controle e o envolvimento existentes no meio rural, dando ao indivíduo maior liberdade. Entretanto, por ser grande demais, a cidade não lhe dá a sensação de a ela pertencer. Ele sente-se mais facilmente isolado que integrado neste sistema que ainda não captou ou conseguiu compreender.

$\mathrm{O}$ primeiro movimento do recém-chegado à cidade ainda é de pertencer a algo. Logo perceberá que os novos vínculos que tenta estabelecer são bem mais fluidos e que os grupos a que pertencia são muito menos sólidos. A maior parte de seus contatos passa a ser secundária. Sua vizinhança, por exemplo, não é mais aquele grupo coeso, mas algo bastante fluido, no qual existem pessoas de posições mais altas e mais baixas que as suas e de cuja existência ou tipo de vida não tem noção. Os edifícios são um exemplo típico disto. Desconhecer quem é o morador do apartamento de baixo ou de cima é um fato corriqueiro.

O novo tipo de família que se constitui passa a ter novos papéis e características. O que ela perde em extensão e quantidade, teria condições de ganhar em profundidade, já que é o único grupo na cidade onde o indivíduo tem maiores possibilidades de integrar todos seus aspectos no relacionamento.

Igualmente para a socialização da criança, a família nuclear urbana exerce um papel mais preponderante que no campo, no qual a criança em idade de socialização sofre influência não só dos pais, mas de outros parentes e vizinhos.

Ocorre que o indivíduo é submetido às mais diversas formas de contato no meio urbano. Se a família é muito importante na socialização da criança na cidade, a própria cidade se encarrega, mais tarde, de se constituir em um modelador de sua personalidade, posto que a submete a diferentes situações e lhe fornece informações.

\section{5 - As regras do jogo}

A cidade caracteriza-se simultaneamente por sua tolerância e indiferença em relação à vida de seus habitantes.

A aspiração a incluir-se no sistema em que a cidade se constitui faz com que os indivíduos aprendam as regras de seu jogo. Cada um está interessado em ser bem sucedido nesta tarefa. O que importa, portanto, é o sucesso pessoal e não o coletivo. Interessa vencer apenas.

Isto, evidentemente, cria uma indiferença para com os demais. A indiferença, igualmente, é um mecanismo de defesa que o indivíduo cria para poder suportar as tensões a que é submetido diariamente. $\mathrm{O}$ conhecido exemplo de muitos não pararem para assistir a alguém que está caído na rua não significa apenas que o cidadão comum não tem tempo a perder na luta diária, mas que se ele for se angustiar com todos os fatos que presencia, sua carga de angústia se tornaria intolerável, impedindo-o de prosseguir.

A maior tolerância que se verifica na cidade é consequência da indiferença. Ambas estão intimamente associadas constituindo-se em faces opostas de uma mesma moeda.

Este contínuo indiferença/tolerância explica, igualmente, mais alguns fenômenos.

O primeiro deles é o que se chama de contraculturas. Estas são formadas por grupos, geralmente jovens, que se recusam a aceitar as regras do jogo que se desenvolve nas grandes cidades. Não se trata de um grupo que tenta se integrar ou combater o sistema, mas de uma 
contestação que se materializa sob forma de recusa. $\mathrm{O}$ exemplo mais atual são os hippies. Ocorre que a relativa tolerância (maior ou menor, de acordo com o grau de urbanização e desenvolvimento do lugar) para com o fenômeno acabou por neutralizá-lo, e de certa forma reintegrá-lo na medida que várias de suas características foram incorporadas e até comercializadas pelo sistema, através de slogans (faça o amor, não a guerra) veiculados pela publicidade ou através de produtos (principalmente a indumentária). Este processo de pseudoabsorção de ideias e costumes hippies conseguiu neutralizar a contestação que o mesmo apresentava no seu surgimento.

O segundo fenômeno é o que Riesman (1950) chama de multidão solitária. Esta é composta por indivíduos que não possuindo o arraigamento e identificação com os valores que o meio rural proporciona, tampouco conseguem identificar-se e assumir uma identidade na cidade. Rodeados constantemente por outros indivíduos, podendo gozar o doce anonimato são no entanto uma massa de solitários que sente a grande cidade como um ambiente de extrema frieza.

O terceiro fenômeno é a procura da privacidade. Submetido diariamente aos mais variados contatos e tensões, o indivíduo sentese invadido em sua intimidade pela constante necessidade de enfrentar e responder a situações e problemas. $\mathrm{O}$ anseio pela privacidade caracteriza uma necessidade de recolhimento e introspeção em busca de restabelecer o equilíbrio pessoal.

O quarto fenômeno é representado pelo episódio relatado no início deste ensaio. O contínuo indiferença/tolerância nos permite agora compreender porque nenhuma das trinta e oito testemunhas tomou qualquer atitude senão a de assistir ao crime. O acontecimento, visto à luz desta explicação, nos permite perceber que não se trata de julgar as testemunhas, mas de compreender o que houve de subjacente a sua passividade e não-envolvimento.

\section{Bibliografia Consultada}

1. MEIER, Richard. A communication theory of urban growth, Cambridge, M.I.T., 1962.

2. MERTON, Robert K. Sociologia, Teoria e Estrutura. São Paulo, Mestre Jou, 1970.

3. RIESMAN, David. The lonely crowd. New Haven, Yale University, 1950.

4. WIRTH, Louis. "O Urbanismo como Modo de Vida”. In: VELHO, O. G. O Fenômeno Urbano. Rio de Janeiro, Zahar, 1967, p. 97-122. 


\section{2 - PROGRESSO, FELICIDADE \& CIA. LTDA.}

Oscar Wilde afirmou que o homem sofre uma desilusão em dois casos: quando seus ideais não se realizam e quando eles se realizam.

Ironia à parte, esta afirmação encerra questões bastante sérias que este ensaio pretende analisar.

Os termos progresso e felicidade são, atualmente, muito empregados, mas pouco questionados. A pergunta que precisa ser formulada é: progredir por quê e para quê? À primeira vista a pergunta pode parecer absurda ou reacionária, mas sua resposta implica em analisar quais são os objetivos a que se pretende chegar com o progresso.

O termo progresso é mais frequentemente utilizado no sentido de progredir por progredir. $\mathrm{O}$ objetivo do progresso seria, então, o próprio progresso, como se ele fosse um valor em si mesmo.

Do mesmo modo, a felicidade é, geralmente, formulada como um ideal. Trata-se de uma caminhada em direção a um objetivo que vai se distanciando à medida que é perseguido. A impossibilidade de alcançar este objetivo está na raiz da felicidade. Atingir o ideal relacionado com a felicidade, provavelmente, traria infelicidade, pois o que torna a ideia de felicidade tão atraente é justamente a dificuldade em alcançá-la.

Para aprofundar as questões que levantei torna-se útil construir um modelo de análise. Ele se constitui de duas sociedades ou culturas. Uma tradicional, a outra moderna. Como exemplos extremos da primeira cultura poderíamos tomar uma tribo indígena e para segunda cultura poderíamos utilizar um país considerado desenvolvido.

Ao primeiro tipo de sociedade costuma-se chamar frequentemente de primitiva, embora vários antropólogos (LEVISTRAUSS, 1970) chamem a atenção para o fato de estas sociedades ou culturas somente serem primitivas na percepção dos observadores oriundos de sociedades não-primitivas. Em verdade elas apresentam uma complexidade e sofisticação de organização social e mental do mesmo nível das sociedades modernas. 
As culturas tradicionais são também, frequentemente chamadas de atrasadas por leigos. Para fazer uma afirmação deste tipo sem falsear a realidade é necessário ter critérios objetivos que possam medir o atraso de uma cultura.

Estes critérios objetivos provavelmente estariam ligados a medir o progresso técnico ou econômico mas certamente se tornariam pouco objetivos ou até ineficazes para medir o progresso social ou a felicidade.

É perfeitamente possível dizer, por exemplo, que uma sociedade possui índices mais favoráveis que outras no que concerne a recursos tecnológicos, à saúde física, recursos postos à disposição do indivíduo, etc. Isto pode ser expresso em indicadores do tipo energia elétrica per capita, expectativa média de vida, renda per capita, etc. Neste sentido o termo desenvolvimento é sempre medido por critérios que refletem o nível tecnológico ou econômico de uma sociedade.

Como medir, entretanto, o nível de progresso social ou de felicidade em bases objetivas? Inevitavelmente incorremos no risco de nos tornarmos etnocêntricos e de considerar e julgar sociedades culturalmente diversas com critérios fornecidos pela nossa própria cultura.

Heródoto relata o diálogo entre alguns gregos e uma tribo bárbara, na qual os primeiros expressam seu horror pelas práticas dos bárbaros em comerem seus mortos, e estes, por seu lado, expressam um quase semelhante horror pela prática de enterrar os mortos, seguida pelos gregos, o que para eles constitui um choque tão grande como os seus próprios costumes para os gregos.

Sobre esta atitude emocionalmente condicionada que se chama de etnocentrismo, o que Heródoto escreveu há séculos permanece válido: "... Se oferecêssemos aos homens a escolha de todos os costumes do mundo, àqueles que lhes parecessem melhores, eles examinariam a totalidade e acabariam preferindo os seus próprios costumes, tão convencidos estão de que estes são melhores que todos os outros"a

Alex Inkeless (1956), em um artigo intitulado "The Modernization of Man" cita nove elementos que julga serem as características do homem moderno. Com bases nestes indicadores foram pesquisadas culturas de diferentes níveis. Entre as características apontadas por Inkeless como sendo as do homem moderno, a maior parte é objetiva, como por exemplo, a disposição para novas experiências e abertura para inovação e mudança, mais fé na ciência e tecnologia, etc.

Ao chegar à sétima característica o autor afirma: "O sétimo tema que enfatizamos é a dignidade. Nós entendemos que o homem mais moderno é alguém que possui mais consciência da dignidade dos outros e maior disposição para mostrar respeito por eles. Nós sentimos que isto fica muito claro em atitudes em relação à mulheres e crianças"

Ao citar a dignidade (medida pelo modo de tratar mulheres e crianças) como uma das características do homem moderno, Inkeless (1956) maneja com indicador que é etnocêntrico. Sabemos que a dignidade é um conceito relativo que varia no tempo e no espaço. E que é encarado por critérios de cada cultura que vão desde a capacidade de sofrer em silêncio até o dever de vingar um parente assassinado. $\mathrm{O}$ modo de tratar mulheres e crianças varia consideravelmente não só entre culturas tradicionais e modernas, mas entre os vários tipos de culturas modernas. O que é mais digno: o costume esquimó de emprestar a mulher ao hóspede ou a obrigação de matar a mulher adúltera?

Analisar outras culturas com bases nos nossos próprios valores não leva a conclusões significativas, porque acaba-se trabalhando com estereótipos, isto é, imagens simplificadas de outras culturas.

${ }^{a}$ BLANKEY, E. H. The history of Herodus. London, Everyman's Library, 1910. V. 1, p. 89

b INKELES, Alex. "The modemization of man". In: WEINER, Myron. Modernization. New York, Basic Books, 1956. p. 144 
No modelo de comparação entre dois tipos de sociedades, não se torna difícil afirmar que as sociedades modernas possuem um grau mais elevado de progresso tecnológico e econômico. Mas do ponto de vista social e emocional é perfeitamente cabível a pergunta: em que todo este progresso tecnológico-econômico levou o homem a ser mais feliz? Ou: não é o homem atrasado mais feliz que o moderno?

A Organização Mundial de Saúde define saúde como "o mais completo bem-estar físico, mental e social"c. Se nos ativermos a esta definição podemos facilmente constatar que as sociedades modernas estão enfermas. Para chegar a tal conclusão bastaria usar indicadores que medissem o bem-estar físico (estatísticas sobre mortalidade e morbidade, assistência médico-hospitalar, nutrição, etc.), o bem-estar mental (índices de suicídios, de alcoólatras e viciados em drogas, internamentos em hospícios, homicídios e outras formas de violência) e o bem-estar social (distribuição de renda, possibilidades educacionais e profissionais, etc).

Surge então a seguinte pergunta: como pode uma cultura que se define como enferma julgar-se o modelo de progresso ou felicidade?

Só é possível analisar culturas com base nos seus próprios valores. Toda cultura possui sua coerência própria e nela várias funções são desempenhadas através de seus elementos culturais. Os costumes e valores servem para a perpetuação de sua configuração sócio-cultural.

Os costumes e valores de uma cultura nem sempre obedecem a um critério de racionalidade e portanto não podem ser analisados sob este ângulo. A tese iluminista da racionalidade humana foi descartada a partir de Freud que mostrou como a conduta humana está eivada de aspectos irracionais e como é motivada pelo inconsciente. Para Freud a irracionalidade é o cerne irredutível do homem e na medida em que as sociedades se organizam elas cerceiam esta irracionalidade.

A repressão social da irracionalidade no indivíduo talvez explique o fato de as sociedades modernas altamente organizadas

c ORGANIZAÇÃO MUNDIAL DA SAÚDE. Constituição, 1948. Constituiçdo da Organizaçdo Mundial da Saúde, aprovada em 7 de abril de 1948. 19. ed. Rio de Janeiro, 1968 apresentarem uma grande incidência de desajustes psicossociais e fenômenos neuróticos. Existe uma relação entre a cultura e a personalidade de seus membros. Toda sociedade, através do processo de socialização, transmite a seus membros seus valores e ideais.

Alguns costumes de certas tribos, como jogar fora uma parte da colheita, podem parecer absurdos sob o ponto de vista estritamente econômico. Nada indica, entretanto, que os membros desta cultura sejam infelizes. Eles seriam infelizes se fossem transportados para uma cultura moderna, do mesmo modo que os membros desta não se sentiriam muito à vontade se tivessem que viver numa tribo.

Tentar impor a culturas tradicionais nossos valores constitui uma forma de violência cultural. Há exemplos muito importantes disso: a aculturação de indígenas tentada por sociedades modernas tem significado frequentemente seu desaparecimento não só cultural, mas físico também.

Ainda no nosso modelo de análise, a sociedade tradicional pode ter valores que a façam mudar pouco. Seus costumes podem ser muito mais em direção à permanência e estabilidade.

É muito frequente que o homem moderno não consiga entender a passividade e a falta de sentido na existência do homem primitivo.

Por trás da tentativa de levar nossa imagem de progresso e felicidade a outras culturas está a ideia ocidental de dar sentido à vida. Esta ideia origina-se no judaísmo e no cristianismo, que dão a vida como sagrada. Para o judaísmo, o homem foi feito à imagem de Deus, e como tal também é santo. A vida seria a situação na qual o homem se santificaria, o que explica porque qualquer preceito religioso não deve ser respeitado se seu cumprimento implicar em perigo à vida. Para o catolicismo a vida terrena é uma preparação para a que vem depois da morte e para o protestantismo uma das funções do homem na terra é glorificar a obra de Deus através da prática de boas ações. Para estas religiões o suicídio é um pecado grave pois implica na destruição de algo sagrado.

Max Weber (1970) mostrou como muitos protestantes associaram a ideia de glorificar a obra de Deus pela prática de boas ações com o ser bem sucedido economicamente. Para Weber a ética 
protestante está fortemente associada ao espírito do capitalismo, na medida em que esta interpretação criou uma motivação muito forte em seus seguidores.

A própria dinamicidade do homem moderno está intimamente associada à sua agressividade e talvez nada mais seja do que uma forma de agressividade canalizada de um modo socialmente aceito. A agressividade comparece entre os valores que o homem moderno recebe de sua cultura e que influencia decisivamente sua personalidade.

Se em outras épocas a agressividade se manifestava mais sob uma forma grupal, modernamente ela surge também sob a forma individual. Para o homem moderno que vive em grandes aglomerados urbanos o que ressalta cada vez mais é a agressividade individual, como algo desejado e reforçado inclusive. Isto se manifesta nas mais variadas formas, principalmente na ideia de vencer na vida, geralmente fundada no princípio de que para uns vencerem, outros precisam sofrer uma derrota.

Um exemplo significativo é o fato de que o empresário dinâmico é comumente chamado de empresário agressivo, sem que esta palavra tenha qualquer conotação pejorativa.

Os padrões de comportamento que as culturas modernas impõem a seus membros envolvem as ideias de sucesso, de consumir e de dinheiro como fontes de felicidade. A ditadura de consumo que se instaurou nos países altamente desenvolvidos, dada a necessidade de as indústrias venderem seus novos produtos, faz com que estes necessitem tornar-se rapidamente obsoletos, a ponto de a obsolescência ser inclusive planejada.

Não parece existir uma correlação positiva entre progresso tecnológico econômico e felicidade. Não há nada que prove que as sociedades que progridem em sua técnica possibilitem a seus membros serem mais felizes. Sobre felicidade estou entendendo a definição de Camus quando afirma: "Mas que é felicidade, senão a simples concordância entre um ser e a existência que leva?"d . Esta

d CAMUS, Albert. “O deserto”, In: _. Bodas em Tipasa. São Paulo, Difusão Européia do Livro, 1964., p.43 definição me parece ser bastante objetiva e não estabelecer juízos de valor.

Se voltarmos ao nosso modelo de análise veremos que o homem de culturas tradicionais pode ter seu esquema de vida relativamente bem organizado e sentir-se seguro por conhecer sua posição dentro da sociedade a que pertence. Como, frequentemente, sua cultura tende mais à permanência, suas ambições são pequenas. $\mathrm{O}$ processo de enculturação faz com que aceite seu status sem preocupação de perdê-lo ou de conquistar outro mais alto. Suas necessidades são simples se comparadas com as do homem de culturas modernas. E, ao contrário deste, não necessita questionar-se tanto a respeito do sentido da vida.

Já as culturas modernas se transformam com muito mais rapidez. A hierarquia social é menos rígida e existe possibilidade de nela baixar e subir; os grupos de fidelidade são muito mais difíceis de identificar. A noção do que é certo e do que é errado também é muito mais flexível.

O processo de enculturação do homem em sociedades modernas frisa a ambição como um valor, pois a cultura é muito mais competitiva. A sociedade de consumo através dos meios de comunicação de massa cria constantemente novas necessidades no indivíduo. Isto faz com que ele desenvolva um nível de aspirações crescentes. Estas são intermináveis pois no momento em que uma é atendida, cria-se uma nova.

A existência do homem moderno, de um modo genérico, gira em torno de sempre aspirar a mais. Este processo apresenta muita semelhança com a noção de felicidade encarada como um ideal inatingível. Pode-se dizer que este empenho por alcançar um ideal inatingível e o infindável processo de ambicionar sempre mais é que produz felicidade ao homem moderno.

A palavra felicidade foi colocada em destaque no parágrafo anterior pois só podemos considerar felizes as pessoas que estiverem em concordância com este tipo de existência que levam. O problema reside justamente no fato de que embora este processo promova o progresso tecnológico-científico, ele não obrigatoriamente promove a 
felicidade, pois o número de pessoas de culturas modernas que não conseguem se ajustar a ele torna-se cada vez maior. É interessante observar que isto se dá com maior intensidade justamente naquelas culturas modernas que possuem o mais alto nível de progresso tecnológico-econômico.

\section{3 - CULTURA E PERSONALIDADE}

Bibliografia Consultada

1. BLANKEY, E. H . The history of Herodutus. London, Everyman's Library, 1910

2. CAMUS, Albert. "o Deserto'. In: - . Bodas em Tipasa. São Paulo, Difusão Européia do Livro, 1964.

3. INKELES, Alex. "The modernization of man". In: WEINER, Myron. Modernization. New York, Basic Books, 1956.

4. LEVI-STRAUSS, Claude. O Pensamento Selvagem. São Paulo, Ed. Nacional, 1970.

5. ANIZAÇÃO MUNDIAL DA SAÚDE. Constituição, 1948. Constituição da Organização Mundial da Saúde, aprovada em 7 de abril de 1948. 19. Ed. Rio de Janeiro, 1968.

6. WERNER, Max. The protestant ethic and spirit of capitalism. 10. Ed. London, Unwin University Books, 1970. 


\section{1 - Introdução}

Analisadas como fenômenos abrangentes, cultura e personalidade se constituem em respostas a necessidades globais: a primeira é a resposta às necessidades da sociedade que a produziu, a segunda é a resposta às necessidades da pessoa na qual se produziu.

Estamos, portanto, diante de dois fenômenos que, embora possuam dinâmicas e leis próprias, guardam certa semelhança por terem como finalidade possibilitar o adequado funcionamento de outros dois fenômenos: a sociedade no caso da cultura e a pessoa humana no caso da personalidade.

Outra analogia que transparece é a de que, por se constituírem num processo dinâmico, as culturas e as personalidades nunca estão completamente integradas, sendo capazes de abranger elementos em conflito e incoerência.

Este artigo pretende abordar o inter-relacionamento entre estes dois fenômenos, ou seja, analisar o papel que a cultura exerce no condicionamento da personalidade e estudar qual é, por sua vez, a influência desta sobre aquela.

Para tal finalidade serão analisadas e discutidas algumas posições de pensadores que se ocuparam com este assunto.

\section{2 - Freud}

Para Freud, os homens são "criaturas em cuja herança instintiva deve ser computada uma poderosa parcela de

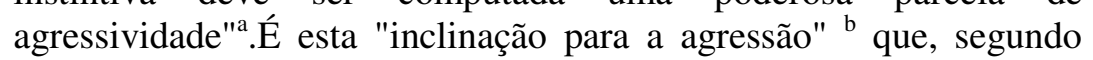
Freud, perturba as relações humanas e que força a cultura a um alto gasto de energia. Como a sociedade civilizada está constantemente ameaçada de desintegração devido a esta hostilidade primordial entre os seres humanos, a cultura tem de usar seus maiores esforços para estabelecer limites aos instintos agressivos do homem.

\footnotetext{
${ }^{a}$ FREUD, Sigmund.Civilization and its discontents. New York, W. W. Norton, 1968. p. 58.
}

b Ibid., p. 59.
"A transformação dos 'maus instintos' é obra de dois fatores que atuam no mesmo sentido, um interno e outro externo. $\mathrm{O}$ fator interno é o influxo exercido sobre os maus instintos - egoístas - pelo erotismo, isto é, pela necessidade de amor no seu mais amplo sentido. A união dos componentes eróticos transforma os instintos egoístas em instintos sociais. O sujeito aprende a estimar e sentir-se amado como uma vantagem pela qual pode renunciar a outras. $\mathrm{O}$ fator externo é a coerção da educação, que representa as exigências da civilização circundante, e é logo continuada pela ação direta do meio civilizado. A civilização tem sido conquistada por obra da renúncia da satisfação dos instintos e exige de todo novo indivíduo a repetição de tal renúncia. Durante a vida individual se produz uma transformação constante da coerção externa em interna. As influências da civilização fazem com que as tendências egoístas sejam convertidas, cada vez mais em maior medida, por agregados eróticos em tendências sociais. Pode-se, por último, admitir que toda coerção interna eficiente na evolução do homem foi, originalmente (isto é, na história da humanidade), tão somente coerção externa. Os homens que nascem hoje trazem consigo certa disposição à transformação dos instintos egoístas em instintos sociais como organização herdada, a qual obediente a leves estímulos, leva a cabo tal transformação. Outra parte desta transformação dos instintos tem de ser levada a cabo na própria vida. Deste modo, o indivíduo não se acha tão somente sob a influência de seu meio civilizado presente, senão que está submetido também à influência da história cultural de seus antepassados"c.

Freud (1930) aponta, também, que o processo da civilização humana e o desenvolvimento ou processo educativo de seres humanos individuais são muito parecidos em natureza se não o mesmo processo aplicado a diferentes tipos de objetos. A meta do primeiro processo seria a criação de um grupo unificado de muitos indivíduos, a do segundo, a integração de um indivíduo separado em um grupo humano.

${ }^{\mathrm{c}}$ FREUD, Sigmund. "Consideraciones de actualidad sobre la guerra y la muerte". In:- . Obras completas de Freud. Madrid, Editorial Biblioteca Nueva, 1948. v. 2, p. 1006-7. 
Há, entretanto, para Freud (1930) uma característica que distingue estes dois processos. No processo de desenvolvimento do indivíduo a principal meta é o programa do prazer, que consiste em encontrar a satisfação da felicidade. Para que esta meta possa ser obtida é necessário que haja integração ou adaptação a uma comunidade humana. Isto significa que o desenvolvimento do indivíduo é um produto de uma interação entre dois impulsos: o impulso à felicidade (geralmente chamada de egoísta) e o impulso à união com outros na comunidade (chamado altruísta). No processo de desenvolvimento individual a principal ênfase recai principalmente no impulso egoísta (no impulso à felicidade), enquanto o outro impulso, descrito como cultural, se contenta, geralmente, com o papel de impor restrições.

Já no processo de civilização a meta mais importante é a de criar uma unidade dos seres humanos individuais. A meta da felicidade, embora presente, é empurrada para o fundo. Quase parece que a criação de uma grande comunidade humana seria bem sucedida se não se prestasse atenção à felicidade do indivíduo.

Assim, pode se esperar que o processo de desenvolvimento do indivíduo tenha especiais características próprias que não são reproduzidas no processo de civilização humana.

Estas colocações de Freud não são aceitas pacificamente por estudiosos do tema "Cultura e Personalidade". As divergências vão desde posturas ingênuas até as que refutam a universalidade do complexo de Édipo e da agressividade humana.

A postura freudiana, na medida que desmascarou a ingenuidade ou hipocrisia subjacente à crença numa natural bondade humana, chocou a muitos para os quais isto implica em aceitar a perspectiva do homo homini lupus que Freud (1930) cita e acolhe em seu livro "Mal-estar na Cultura", obra na qual desenvolve suas principais ideias sobre o tema.

O importante é distinguir o modo pelo qual é focada a divergência sobre a bondade ou maldade humanas como característica biológica. Esta divergência pode ser abordada por um enfoque passional ou dogmático, como por um enfoque mais científico.

3.3 - Koestler

Para Arthur Koestler (“Todo Homem é uma Ilha"), por exemplo, o exame da história humana leva à conclusão de que o homem sofre de uma perturbação mental congênita que o impele à destruição. Mas para este autor, "o principal problema com o homem parece ser, não que se trata de uma criatura excessivamente agressiva, mas uma criatura excessivamente local e dedicada" ${ }^{\mathrm{d}}$.

Aponta Koestler que a "maior parte das civilizações foi bem sucedida na tarefa de controlar a agressividade individual e de ensinar aos jovens como sublimarem seus impulsos de arrogante autodestruição. Mas fracassamos tragicamente na comparável tarefa de se conseguir a sublimação e canalização das emoções autotranscendentais" e

Embora séria, a formulação de Koestler não leva em conta um aspecto muito importante, que é o fato da agressividade coletiva e a devoção a um grupo ser fruto da agressividade individual. A agressividade individual não é tolerada pela sociedade civilizada, mas a agressividade coletiva é por ela tolerada e estimulada. Este processo, descrito por Freud em Totem e Tabu (1913) corresponde ao pacto que a horda primitiva fez e corresponde ao modelo de qualquer guerra. $\mathrm{O}$ grupo ou o estado assume coletivamente a agressividade que é proibida individualmente.

\section{4 - Bertrand Russell}

Ainda na linha de dar primazia às características inatas, Bertrand Russell (1957) afirma que uma das principais diferenças entre o

\footnotetext{
${ }^{\mathrm{d}}$ KOESTLER, Arthur. Todo Homem é uma Ilha. Copenhague, s. d. Mimeografado. p. 1. Discurso proferido ao receber o prêmio Sonning.

${ }^{\mathrm{e}}$ Ibid, p. 2
} 
homem e o animal é que alguns desejos humanos, ao contrário dos desejos manifestados pelos animais são essencialmente ilimitados e incapazes de satisfação completa.

Para Russell os principais desejos infinitos do homem são os de poder e de glória, que só são limitados pelo que a imaginação sugere como possível. Existe, para Russell, em todo o homem, em menor ou maior escala, o desejo de ser Deus. É isto que torna difícil a cooperação social, pois cada um de nós gostaria de concebê-la, segundo o modelo de cooperação entre Deus e Seus adoradores, com nós mesmos colocados no lugar de Deus. Daí a concorrência, a necessidade de compromissos e de governo, o impulso à rebelião, com a instabilidade e a violência periódicas. E daí a necessidade de moralidade para reprimir a auto-afirmação individual.

O enfoque de Russell introduz na análise do comportamento social uma variável de fundamental importância. Perceber que o impulso para o poder é o principal móvel do comportamento social, significa analisar a este como resultado de impulsos humanos e não de ações gratuitas. Estamos novamente diante de uma análise que mostra que as ações humanas não são casuais mas têm profundas raízes subjacentes.

Nos três autores anteriormente citados (Freud, Koestler e Russell), existe acentuada valorização das forças biológicas primárias (instintivo-emocionais), no confronto entre o individual com o social. A atuação humana seria essencialmente explicada pela biologia dos instintos do homem, sendo as outras causas e circunstâncias complementares ou secundárias. É claro que este enfoque não é aceito unanimemente por todos que se interessam pelo tema "Cultura e Personalidade". Posições divergentes são encontradas entre antropólogos, sociólogos e mesmo entre psicanalistas (escola culturalista). Existe toda uma corrente de pensamento que valoriza muito mais os fatores sócio-culturais em detrimento das forças biológicas primárias, acentuando o papel da cultura, em vez dos instintos, na explicação do comportamento humano.

\section{5 - Malinowski e Radcliffe-Brown}

A escola antropológica funcionalista (ou estrutural-funcional) tomou impulso com Malinowski e Radcliffe-Brown, e desenvolveu duas tendências teóricas diferentes. A posição funcionalista de Malinowski ressalta as necessidades dos indivíduos, enquanto Radcliffe-Brown e seus seguidores acentuam as necessidades dos sistemas sociais.

Para Malinowski (1962) cada cultura é um todo operante, uma unidade integrada, na qual cada elemento tem uma contribuição funcional a prestar. A função de qualquer instituição, vale dizer, de um sistema organizado de atividade, é a parte que ela representa no todo interligado, preenchendo propósitos ou necessidades humanas

Para Radcliffe-Brown (1959) a função de um elemento de cultura é o papel que ele representa em toda vida social e, portanto, a contribuição que presta à manutenção da continuidade estrutural.

Malinowski (1949) durante toda Primeira Guerra Mundial, esteve ao largo da costa da Nova Guiné pesquisando quase todos os aspectos do modo de vida dessas ilhas e concluiu que os nativos das ilhas de Trobriand constituíam uma negação do complexo de Édipo.

Os trobriandinos são matrilineares na organização do parentesco, ou seja, a relação de parentesco se deriva exclusivamente da mãe e os direitos de sucessão e herança só se regem em linha materna.

Entre os trobriandinos, Malinowski verificou que a crescente hostilidade do menino é dirigida não para o pai, mas contra o tio materno, porque este é a pessoa que tem autoridade sobre ele, quem o educa para a vida adulta. O pai é uma pessoa amiga, prestativa, que exerce pouca ou nenhuma autoridade sobre o filho. Malinowski também descobriu que a culpa sexual em relação a desejos proibidos incluía não a mãe, mas a irmã. 
O trabalho de Malinowski foi muito criticado (RÔHEIM, 1958) por não ter ele percebido que pelo processo de transferência psicológica, o complexo de Édipo estava deslocado sobre substitutos como tios, irmãos, etc, e que portanto não foi refutado pelos trobriandinos matrilineares.

\section{6 - Durkheim}

De acordo com Émile Durkheim (1930) cientista social francês que influenciou a corrente funcionalista (principalmente a RadcliffeBrown), as necessidades humanas, ao contrário dos animais, são passíveis de uma expansão infinita. Como não existe um limite natural ao que o homem possa desejar e, portanto, ao que lhe possa proporcionar um sentido de satisfação e realização, o limite dos desejos humanos não é estabelecido pela biologia, mas por regras sociais que definem para cada tipo de homem, aquilo a que legitimamente tem direito. Incorporadas à consciência do indivíduo, essas regras estabelecem e disciplinam as aspirações dos homens e criam a possibilidade de um modelo de satisfação e realização.

Em oposição aos pensadores do utilitarismo, para os quais a felicidade humana consistia num constante alargamento, em tamanho e quantidade, dos prazeres individuais, para Durkheim a felicidade humana só poderia ser obtida se os prazeres individuais fossem limitados por normas socialmente aceitas. Quando estas normas falhassem, o indivíduo se acharia num estado de desorganização pessoal que ele chamou de anomia e que aplicou à divisão do trabalho e ao suicídio.

A noção durkheimiana (1938) de anornia surgiu na explicação das formas e consequências patológicas da divisão do trabalho, principalmente a frequente tendência de uma divisão cada vez maior do trabalho ser acompanhada por uma coordenação imperfeita das partes, redução da solidariedade social e conflito entre as classes sociais. De acordo com Durkheim, essas condições surgiam quando os indivíduos que desempenham as várias funções especializadas da divisão do trabalho não possuíam, entre si, uma integração suficientemente estreita e contínua que possibilitasse o crescimento gradativo de um sistema de regras e entendimentos comuns.

$\mathrm{Na}$ falta de tais regras, aumenta a incerteza e a imprevisibilidade, não sendo possível harmonizar as ações dos indivíduos de um setor da divisão do trabalho com as ações das pessoas nos outros setores, e as pessoas são dominadas por objetivos contraditórios, o que causa confusão, realização ineficiente de funções sociais fundamentais e tendências à desintegração social. Em resumo: desintegra-se o corpo de regras comuns que é o principal mecanismo de regulamentação das relações entre os elementos do sistema social. A este estado de ausência de normas e desregulamento, Durkheim denominou de anomia.

\section{7 - Merton}

Robert Merton (1970), sociólogo norte-americano, seguidor e reformulador do funcionalismo, considera falaz a premissa de que a estrutura da sociedade restrinja primordialmente a livre expressão dos impulsos nativos fixos do homem. Para Merton, "a filosofia contida em tal doutrina é, evidentemente, o anarquismo cru; ou o anarquismo benevolente, como é o caso de Fromm, ou algumas vezes, como é o caso de Freud e Hobbes, uma concepção de anarquismo como sendo malevolente, no qual o homem é visto como entrando num contrato social destinado a protegê-lo desta malevolência. Em qualquer destes casos, a estrutura social é considerada como um mal necessário, originando-se a princípio dos impulsos hostis e depois restringindo sua livre expressão"f. Em contraste com tais doutrinas anarquistas, Merton numa linha de análise funcionalista concebe a estrutura social como ativa, como produtora de novas motivações que não podem ser preditas sobre a base do conhecimento dos impulsos do homem: "Se a estrutura social restringe algumas disposições para agir, cria outras. $\mathrm{O}$ enfoque funcional, portanto, abandona a posição mantida por várias teorias individualistas, de que as diferentes proporções de

\footnotetext{
f MERTON, Robert K. Sociologia, Teoria e Estrutura. São Paulo, Mestre Jou, 1970. p.
} 191 
comportamento divergente, nos diversos grupos e estratos sociais, são o resultado acidental de proporções várias de personalidades patológicas encontradas em tais grupos e estratos. Ao invés, tenta determinar como a estrutura social e cultural gera a pressão favorável ao comportamento socialmente desviado, sobre as pessoas localizadas em várias situações naquela estrutura"g.

Retomando o tema durkheimiano da anomia, Merton publicou em 1938 um artigo chamado "Estrutura Social e Anomia"h. Nele explicita uma distinção tríplice que estava implícita na análise de Durkheim.

Entre os diversos elementos, das estruturas sociais e culturais teríamos em primeiro lugar os "objetivos culturalmente definidos" de propósitos e interesses, mantidos como objetivos legítimos para todos, ou para membros diversamente localizados na sociedade. E embora alguns, não todos, de tais objetivos culturais sejam diretamente relacionados aos impulsos biológicos do homem, não são por eles determinados.

Em segundo lugar, existem as "normas" que definem, regulam e controlam os modos aceitáveis de alcançar tais objetivos.

Em terceiro lugar, temos os "meios institucionalizados", que são a verdadeira distribuição de oportunidades e habilidades, a fim de atingir, de maneira compatível com as normas, os objetivos culturais. Constituem um aspecto da estrutura social, as condições objetivas de ação.

A interação destas três variáveis determina a distribuição da "tensão socialmente estruturada". A estrutura cultural pode determinar objetivos semelhantes para todos os membros da sociedade, ou objetivos diferentes para pessoas em posições sociais diferentes. Pode estabelecer regras para alcançar os objetivos que sejam iguais para todos os membros da sociedade ou pode proibir aos membros de uma posição o que permite aos de outra.

\footnotetext{
g Ibid., p. 191

${ }^{\text {h }}$ Ibid p. 203-34.
}

Em um caso limite teríamos então sociedades em que é dada uma ênfase excepcionalmente forte sobre objetivos específicos, sem uma correspondente ênfase sobre os procedimentos institucionais; noutro caso limite a ênfase recai toda sobre os procedimentos institucionais, ao passo que as atividades inicialmente concebidas como instrumentais são transformadas em práticas autocontidas, que carecem de ulteriores objetivos.

Para Merton (1970) na sociedade norte-americana ocorre grande ênfase sobre objetivos de êxito (principalmente pelo triunfo monetário ou material) para pessoas de todas as classes, sem a ênfase equivalente sobre os meios institucionalizados.

A separação entre objetivos e meios e a consequente tensão provocam a redução da dedicação dos indivíduos aos objetivos culturalmente determinados ou aos meios institucionalizados, isto é, provocam um estado de anomia.

O conceito mertoniano de anomia parte da análise da relação entre a estrutura cultural, de um lado, e a estrutura social, de outro. A estrutura cultural é definida por Merton (1970) como sendo o conjunto de valores normativos que governam a conduta comum dos membros de uma determinada sociedade ou grupo, ao passo que a estrutura social é entendida como o conjunto organizado de relações sociais no qual os membros da sociedade ou grupo são implicados de várias maneiras.

A anomia é então concebida, por Merton, como uma ruptura na estrutura cultural, ocorrendo, particularmente, quando há uma disjunção aguda entre as normas e metas culturais e as capacidades socialmente estruturadas dos membros em agir de acordo com as primeiras. Conforme esta concepção, os valores culturais podem ajudar a produzir um comportamento que esteja em oposição aos mandatos dos próprios valores.

Construindo uma tipologia de adaptação individual em função de duas variáveis (objetivos culturais e meios institucionalizados de alcançá-los), Merton montou uma tabela com cinco tipos de 
adaptações, na qual ambas as variáveis podem ser aceitas ou rejeitadas.

A seguinte tabela apresenta os cinco tipos de adaptação, em que (+) significa "aceitação",(-) significa "rejeição", e ( \pm ) significa "rejeição de valores predominantes e sua substituição por novos valores".

\section{Tipologia de Modos de Adaptação Individual ${ }^{\mathrm{i}}$}

Modos de Adaptação Metas Culturais

Meios

institucionalizados

\section{I - Conformidade \\ II - Inovação \\ III - Ritualismo \\ IV - Retraimento \\ V- Rebelião}

Apenas o primeiro tipo de adaptação (conformidade) é de aceitação das duas variáveis desta tipologia. Os outros tipos de adaptação configuram-se como formas de comportamento desviado. Assim, os inovadores (por exemplo, criminosos de classe média) assimilam a ênfase cultural sobre o alvo a alcançar sem, ao mesmo tempo, absorver igualmente as normas institucionalizadas que dirigem os meios e processos para seu atingimento.

Os ritualistas (por exemplo, burocratas que obedecem servilmente as regras sem levar em conta suas finalidades) abandonam os objetivos culturais e prendem-se às normas institucionalizadas, das quais fazem uma virtude. Os que se retraem (por exemplo, psicóticos, certos artistas, párias, proscritos, errantes, mendigos, bêbados crônicos e viciados em drogas) rejeitam tanto os

\footnotetext{
${ }^{\text {i }}$ Ibid, p. 212
}

objetivos culturais, como os meios institucionalizados, pertencendo à sociedade somente num sentido fictício.

Já a rebelião (exemplificada por membros de movimentos revolucionários) pressupõe o afastamento dos objetivos dominantes e sua substituição por novos valores.

Como é fácil observar, a abordagem de Merton é radicalmente sociológica, na medida em que situa o indivíduo no confronto com a estrutura social e cultural à qual pertence, e rejeita a predominância dos fatores biológicos como determinantes da conduta humana.

\section{8 - Estudos psicológicos e culturalistas}

Existe, ainda, toda uma corrente com expressões tanto na antropologia, como na psicanálise, que procurou estudar as relações entre a cultura e a personalidade de seus membros. $\mathrm{Na}$ antropologia, a maior parte se constituía em discípulos de Franz Boas (1911) que lecionava antropologia na Universidade de Columbia, e seus trabalhos são geralmente conhecidos por "estudos psicológicos e de configuração ou estudos de cultura e personalidade". Entre os nomes que mais se destacaram encontram-se Edward Sapir (1949), Ruth Benedict ("Padrões de Cultura", s.d.), Margaret Mead (1969), Ralph Linton (1962), Clyde Kluckhohn (1963) e Cora DuBois (1955).

$\mathrm{Na}$ psicanálise esta corrente é geralmente chamada de "culturalista" e entre seus membros encontram-se, por exemplo. Abram Kardiner (1968), Erich Fromm (1963), Karen Horney (1960), Harry Stack Sullivan (1962) e Erick Erickson (1963).

Houve, inclusive, colaboração entre antropólogos e psicanalistas, como no caso de Ralph Linton (1967 e 1962) e Abram Kardiner (1955 e 1968).

Margaret Mead realizou vários estudos em culturas simples, procurando estudar a personalidade de seus membros. Em Coming of Age in Samoa, Mead (1928) informa que o tipo de vida que os samoanos levam é contrária aos laços emocionais característicos da 
situação edipiana, pelo tipo de relacionamento de irmãos, irmãs e primos sem quaisquer restrições na vida instintiva, com dispersão de afetos dos adultos que convivem com eles na mesma habitação. Esta situação foi encontrada por Mead em várias outras culturas, o que a levou à conclusão de que o conflito não faz parte da natureza humana, mas depende de fatores culturais que atuam na organização familiar.

Em seu livro "Sexo e Temperamento", por exemplo, Mead (1969) descreve três tribos (Arapesh, Mundugumor e Tchambuli) situadas dentro de uma área de cem milhas na Nova Guiné. Procurando estudar as diferenças sexuais entre estas tribos, Mead constatou que "numa delas, homens e mulheres agiam como esperamos que as mulheres ajam de um suave modo parental e sensível; na segunda, ambos agiam como esperamos que os homens ajam: com bravia iniciativa; e na terceira, os homens agem segundo o nosso estereótipo para as mulheres, são fingidos, usam cachos e vão às compras, enquanto as mulheres são enérgicas, administradoras, parceiros desadornados" $\mathrm{n}$.

Para Ralph Linton, "tomada como um todo, uma cultura é uma resposta às necessidades totais da sociedade que a produziu"k .

Linton (1967) afirma que existem dois tipos de influências completamente distintas que são exercidas sobre o desenvolvimento da personalidade. Por um lado, existem as influências que se originam da conduta culturalmente padronizada de outras pessoas "para com” a criança. Estas influências começam a operar desde o nascimento e são de fundamental importância durante a infância. Por outro lado, existem as influências que se originam da observação ou instrução que o indivíduo tem dos padrões de conduta característicos de sua sociedade. Embora muitos desses padrões não o afetem diretamente, eles fornecem-lhe modelos para o desenvolvimento de suas próprias reações habituais às várias situações. E, embora careçam de importância na primeira infância, continuam a afetá-lo durante a vida.

${ }^{\mathrm{j}}$ MEAD, Margaret. Sexo e Temperamento. São Paulo, Perspectiva, 1969. P. 10

${ }^{k}$ LINTON, Ralph. O Homem: uma Introdução à Antorpologia. São Paulo, Martins, 1962. P. 330
Linton (1962) também se preocupa com o grau de integração necessário à sobrevivência de uma cultura. Para ele, nenhuma cultura jamais estará em estado de integração perfeita, isto é, nunca terá todos os seus elementos em condição de ajustamento recíproco completo, enquanto mudanças de qualquer natureza estiverem em andamento. E como sempre está se processando alguma modificação, por causa da invenção ou da difusão, nenhuma cultura está perfeitamente integrada, em qualquer época de sua história. Por isto, a integração é uma questão de grau, para Linton.

Existiria um ponto mínimo de integração, abaixo do qual a cultura se paralisaria e consequentemente a sociedade como entidade funcional, seria destruída. Entretanto, raramente ou nunca este ponto seria alcançado.

Para Linton, a cultura é essencialmente um fenômeno sóciopsicológico e, portanto, o grau de integração necessário a seu bom funcionamento não é comparável ao grau de integração necessário ao bom funcionamento de um organismo.

Apenas em dois pontos de toda configuração cultural a falta de ajustamento pode ter efeito paralisador, segundo Linton: "Um destes é o centro da cultura, a massa de valores, associações e reações emocionais condicionadas, em grande parte inconscientes, que dão à cultura sua vitalidade e fornecem aos indivíduos os motivos para aderir aos padrões culturais e praticá-los. O outro é a mais superficial das zonas de cultura, a zona dos padrões habituais de comportamento expresso. Desajustamentos no primeiro ponto produzem conflitos emocionais constantes dentro do indivíduo; conflitos entre indivíduos que preferem valores diferentes; e perda da unidade psicológica. Desajustamentos no segundo ponto resultam em constante interferência, em desperdício de movimentos, para não falar num estado crônico de irritação"1.

Linton e Abram Kardiner desenvolveram, durante aproximadamente cinco anos, na Universidade de Columbia um seminário interdisciplinar no qual eram apresentados informes do

${ }^{1}$ Ibid.p.387-8 
estilo de vida de várias culturas que eram analisadas sob os enfoques antropológico e psicanalítico.

Deste seminário surgiu o conceito de "personalidade básica", lançado por Kardiner (1955) como sendo a configuração de personalidade compartilhada pela maioria dos membros de sociedade em consequência das primeiras experiências que tiveram em comum.

\section{9 - Conclusão}

As posições existentes sobre o tema "Cultura e Personalidade" nos colocam diante da clássica questão: quem surgiu primeiro, a galinha ou o ovo? Vale dizer, é a cultura que molda a personalidade de seus membros, ou são as características instintivas destes, responsáveis pela existência da cultura?

Os defensores de ambas as posições são capazes de apontar evidências que comprovem seu acerto. Como, entretanto, em matéria de conhecimento humano é possível encontrar dados que comprovem qualquer teoria (POPPER, 1967) isto não nos tira do impasse.

O importante, pois, não é determinar onde se localiza o começo do problema, mas constatar que se trata de um processo dinâmico no qual causas e efeitos se confundem e agem um sobre o outro.

Se reconhecermos a existência de um tipo básico de estrutura psíquica nas sociedades onde há uma família do tipo patrilinear, condicionada por necessidades biológicas e sócio-culturais, podemos analisar qual é a influência que a cultura exerce sobre a mesma.

Para que uma cultura possa subsistir, é preciso que haja uma adequada socialização de seus membros, que tenha como resultado a integração da maior parte deles na sociedade.

Considerando a socialização como o processo pelo qual é inculcada a estrutura de ação de uma sociedade no indivíduo ou grupo, teremos dois tipos de influências socializadoras. A primeira ocorre na infância, na qual a agência socializadora é principalmente a família; a segunda se processa posteriormente nos múltiplos contatos e vivências que os indivíduos experimentam, quando são várias as agências socializadoras.

Sendo, entretanto, a família, por sua vez, também um produto cultural, nela são reproduzidos padrões e valores vigentes na cultura. Deste modo, a socialização que ocorre na família incute valores e padrões da sociedade da qual aquela faz parte. Igualmente, os membros mais velhos da familia-agência-socializadora foram previamente socializados de acordo com os padrões culturais vigentes.

Sendo a personalidade fortemente marcada pelos primeiros anos de vida, nos quais a influência preponderante é a família, o indivíduo tenderá a reproduzir em sua conduta futura, os padrões culturais que adquiriu no relacionamento familiar, envolvendo autoridade, ambição, motivações, expectativas, segurança, autoestima etc.

Por outro lado, cada cultura tende a criar em seus membros um determinado tipo de motivações para o qual o indivíduo é preparado, primeiramente na família e posteriormente em outras situações.

Por fazerem parte de um processo dinâmico, estas motivações estão em constante modificação. Determinado tipo de estrutura cultural cria certas motivações; estas por sua vez retroagem sobre a estrutura cultural, sem que seja possível determinar onde começou o processo.

\section{Bibliografia Consultada}

1. BENEDICT, Ruth. Padrões de Cultura. Lisboa, Livros do Brasil, s. d.

2. BOAS, Franz. The mind of primitive man. New York, Macmillan, 1943. Escrito em 1911.

3. DUBOIS, Cora. The dominant value profile of american culture. American Anthropologist, Washington, D. C., 57:1232-9, 1955.

4. DURKHEIM, Émile. De la division du trarvail social. Paris, Félix Alcan, 1938. Escrito em 1893 
5. — . Le suicide. Paris, Félix Alcan, 1930. Escrito em 1897.

6. ERIKSON, Erik H. Childhood and society. New York, W. W. Norton, 1963.

7. FREUD, Sigmund. Civilization and its discontents. New York, W.W. Norton, 1968. Escrito em 1930.

8. - . "Consideraciones de actualidad sobre la guerra y la muerte". In: Obras completas de Freud. Madrid, Editorial Biblioteca Nueva, 1948. v. 2, p. 1006-7. Escrito em 1915.

9. —. Totem e Tabu. Rio de Janeiro, Delta, s.d. Escrito em 1913.

10. FROMM, Erich. Psicanálise da Sociedade Contemporânea, Rio de Janeiro, Zahar, 1963.

11. HORNEY, Karen. La personalidad neurótica de nuestro tiempo. Buenos Aires, Paidós, 1960.

12. KARDINER, Abram. Fronteiras psicológicas de la sociedad. México, México, Fondo de Cultura Económica, 1955.

13. - El individuo y su sociedad. México, Fondo de Cultura Económica, 1968.

14. KLUCKHOHN, Clyde. Antropologia; um Espelho para o Homem. Belo Horizonte, Itatiaia, 1963.

15. KOESTLER, Arthur. Todo Homem é uma Ilha. Copenhague, s.d. Mimeografado. Discurso proferido ao receber o prêmio Soning.

16. LINTON, Ralph. Cultura e Personalidade. São Paulo, Mestre Jou, 1967.

17. - . O Homem: uma Introdução à Antropologia. São Paulo, Martins, 1962.

18. MALINOWSKI, Bronislaw. Estudios de psicologia primitiva. Buenos Aires, Paidós, 1949.

19. - Uma Teoria Científica da Cultura. Rio de Janeiro, Zahar, 1962.

20. MEAD, Margaret. Coming of age in Samoa. New York, Morrow, 1928.

21. - Sexo e Temperamento. São Paulo, Perspectiva, 1969.
22. MERTON, Robert K. Sociologia, Teoria e Estrutura. São Paulo, Mestre Jou, 1970.

23. POPPER, Karl R. El desarollo dei conocimiento científico. Buenos Aires, Paidós, 1967.

24. RADCLIFFE-BROWN, Alfred Reginald. Structure and function in primitive society. London, Cohen and West, 1959.

25. RÓHEIM, Geza. "Psicoanálisis y antropologia". In: JONES, Ernest et alii. Sociedade, cultura y psicoanálisis. Buenos Aires, Paidós, 1958.

26. RUSSELL, Bertrand. O Poder, uma Nova Análise Social. São Paulo, Ed. Nacional, 1957.

27. SAPIR, Edward. Selected writings of Edward Sapir in language, culture and personality. Berkeley, University of California, 1949.

28. SULLIVAN, Harry Stack. Fusion of psychiany and social science. New York, Norton, 1962. 
Coabitou o homem com Eva, sua mulher. Esta concebeu e deu à luz a Caim; então disse: Adquiri um varão com o auxílio do Senhor.

Depois deu à luz a Abel, seu irmão. Abel foi pastor de ovelhas e Caim, lavrador.

\section{4 - O MITO DE ABEL E CAIM E O SURGIMENTO DA CIDADE BÍBLICA}

Aconteceu que no fim de uns tempos trouxe Caim do fruto da terra uma oferta ao Senhor.

Abel, por sua vez, trouxe das primícias do seu rebanho, e da gordura deste. Agradou-se o Senhor de Abel e de sua oferta; ao passo que de Caim e de sua oferta não se agradou. Irou-se, pois, sobremaneira Caim, e descaiu-lhe o semblante.

Então lhe disse o Senhor: Por que andas irado? E por que descaiu o teu semblante?

Se procederes bem, não é certo que serás aceito? Se todavia, procederes mal, eis que o pecado jaz à porta; o seu desejo será contra ti, mas a ti cumpre dominá-lo.

Disse Caim a Abel, seu irmão: Vamos ao campo. Estando eles no campo, sucedeu que se levantou Caim contra Abel, seu irmão e o matou.

Disse o Senhor a Caim: Onde está Abel, teu irmão? Ele respondeu: Não sei: acaso sou eu tutor de meu irmão?

E disse Deus: Que fizeste? A voz do sangue do teu irmão clama da terra a mim.

És agora, pois, maldito por sobre a terra cuja boca se abriu para receber de tuas mãos o sangue de teu irmão.

Quando lavrares o solo não te dará ele a sua força; serás fugitivo errante pela terra.

Então disse Caim ao Senhor: É tamanho o meu castigo, que já não posso suportá-lo.

Eis que hoje me lanças da face da terra, e de tua presença hei de esconder-me; serei fugitivo e errante pela terra: quem comigo se encontrar me matará

O Senhor, porém, lhe disse: Assim qualquer que matar a Caim será vingado sete vezes. E pôs o Senhor um sinal em Caim para que o não ferisse de morte quem quer que o encontrasse. 
Retirou-se Caim da presença do Senhor e habitou na terra de Node, ao oriente do Éden.

E coabitou Caim com sua mulher; ela concebeu e deu à luz a Enoque. Caim edificou uma cidade e lhe chamou Enoque, o nome de seu filho. ${ }^{a}$

\section{1 - O aspecto histórico-social}

Ao nível histórico-social, uma primeira análise poderia levar-nos a explicar o mito de Caim e Abel como um registro dos conflitos da antiga Palestina, entre pastores nômades e agricultores.

Entretanto, isto não explicaria porque Caim não foi um pastor nômade e portanto propenso a roubar e assassinar o agricultor pacífico - mas um agricultor, enquanto Abel era o pastor.

Outra explicação tenderia a interpretar o mito historicamente do seguinte modo: pastores famintos irrompem numa área de agricultura estável durante uma seca e são aceitos como hóspedes pagadores de tributos. Posteriormente, eles exigem uma participação no governo. Sacrifícios simultâneos à deidade estatal são então oferecidos por ambas as partes. A oferenda do chefe dos pastores é preferida; com o que o chefe dos agricultores, auxiliado por seus parentes maternos o assassina. Como consequência, os agricultores são expulsos e eventualmente fundam uma cidade-estado noutro lugar.

Esta situação política tem sido frequente na África Oriental durante séculos: pastores intrusos, que primeiro aparecem como suplicantes famintos, adquirem ascendência política, depois de terem despertado grave antagonismo por deixarem seus animais pisotearem as colheitas.

Outra explicação considera que o sinal colocado em Caim provavelmente era o sinal totêmico de seu clã, e que de fato todo o

${ }^{a}$ GÊNESIS 4 : 1-17. In: BÍBLIA. Português. Bíblia Sagrada. São Paulo, Paulinas, 1969. p $27-8$ episódio encerra uma contenda tribal primitiva pela hegemonia nas mais remotas eras da história do mundo.

4.2 - A análise do mito

Na cosmogonia bíblica, o surgimento da inteligência humana está diretamente associado à noção do bem e do mal, à prática do pecado e à noção de responsabilidade.

O paraíso representa um mundo no qual os homens têm todas suas necessidades atendidas e no qual inexistem conflitos. Homem e natureza vivem em perfeita harmonia.

Apenas uma proibição e consequente tentação destoa do quadro geral: a árvore do bem e do mal. Toda dádiva do ambiente paradisíaco está condicionada a não experimentar da árvore do bem e do mal. Esta proibição, entretanto, não exclui a possibilidade de infringi-la. Ao contrário de outras mitologias, não há a ideia da predestinação. Enquanto na mitologia grega, Édipo está predestinado a matar seu pai e juntar-se com sua mãe (sendo todas suas tentativas de impedir a profecia do oráculo, fracassadas), na mitologia bíblica existe livre arbítrio. Há uma proibição, mas é o Homem que decidirá acatá-la ou não.

A infração da proibição simboliza o começo da história humana. O Homem passa a ser conhecedor do bem e do mal. Sente vergonha (de estar despido) e aprende que sua ousadia em desafiar a autoridade divina será punida. À transgressão da norma corresponde a vergonha e o castigo.

Este é constituído pela expulsão do Éden e pelas consequentes dificuldades decorrentes da ruptura entre o Homem e a natureza: dores do parto, ganhar o pão de cada dia com o suor da face.

Ao nível de transgressão e castigo, a punição recebida por Adão e Eva, embora angustiante, oferece a vantagem de expiar uma eventual culpa. A expiação da culpa é um dos elementos-chaves de todo castigo. Com o castigo o infringido (Deus, a sociedade, o 
prejudicado pela infração) pune o infrator, ao passo que este paga ao infringido por seu ato.

Entretanto, com Caim verifica-se uma situação sui generis. O castigo que recebe é muito mais vago que o de seus pais. Estes estavam atingidos pelo sentimento de vergonha; Caim é atingido pelo sentimento de culpa.

Deus o responsabiliza pelo fratricídio. Se ao Homem é dada a possibilidade de escolher, esta vem acompanhada da responsabilidade que cada escolha acarreta.

Adão e Eva escolhem comer do fruto proibido e têm de arcar com as consequências que o conhecimento do bem e do mal trazem.

Caim escolhe matar seu irmão e tem de responder por seu ato, mesmo que a princípio não o queira ("Acaso sou eu tutor de meu irmão?").

Adão e Eva desconheciam a noção do bem e do mal, quando comeram do fruto proibido, não podendo portanto sentir-se culpados; Caim, entretanto, nasceu num mundo onde esta noção já existia.

O castigo de Caim é carregar eternamente a culpa de seu ato. Quando Deus lhe comunica que é maldito na terra e que esta não mais lhe dará frutos, sendo, portanto, fugitivo e errante, Caim exclama: "É tamanho o meu castigo que já não posso suportá-lo". A punição que Deus lhe impôs é terrível justamente por dois motivos: 1) não permitir a expiação do crime; 2) (por conseguinte) impedir sua reintegração na sociedade (será fugitivo e errante).

E, diante da argumentação de Caim de que será morto por quem o encontrar, Deus reforça o castigo: coloca-lhe um sinal (que o diferencia dos outros homens, impedindo-o de esquecer ou ocultar seu crime) e determinando que quem o matar (ser assassinado seria uma forma de expiar o assassinato por ele cometido) será vingado sete vezes.

É neste clima que vem a surgir a primeira cidade bíblica. Caim depois da sentença a que foi condenado edifica uma cidade à qual dá o nome de seu filho Enoque.
A construção de uma cidade com o nome de seu filho pode ser interpretada com um duplo sentido reparador do crime: 1) a construção de algo para compensar a destruição de uma vida; 2) fazer renascer a Abel nesta construção, dando-lhe o nome de seu filho. Neste sentido, o filho representa o irmão mais moço que assassinou e ao qual restaura a vida simbolicamente.

Também poder-se-ia ver no ato de Caim um modo de amenizar a maldição sobre ele lançada: já que não pode mais ser lavrador como antes, estabelece-se em algo no qual a terra não é o elemento central e no qual se encontra ao abrigo de possíveis ataques.

$\mathrm{Na}$ mitologia bíblica, a primeira cidade nasce, portanto, como decorrência de um crime, mais especificamente de um fratricídio, e possui um sentido reparador.

$\mathrm{O}$ assassinato de Abel pode ser interpretado não somente como um fratricídio, mas também, indiretamente, como um parricídio. Rejeitado pelo pai (simbolizado em Deus), que não se agradou de sua oferta, Caim resolve matá-lo. Na impossibilidade de atingi-lo diretamente, mata-o de modo simbólico, destruindo seu filho Abel pelo qual fora preterido.

É interessante ressaltar a raiz etimológica do nome Enoque. Em hebraico a raiz triletral da qual é composto o nome é a mesma que corresponde aos verbos (e substantivos que deles derivam) inaugurar e educar. Seria possível, levando o raciocínio mais além, estabelecer várias suposições com base nesta semelhança etimológica, principalmente se considerarmos que em hebraico a parte fixa de uma palavra é composta por sua raiz (geralmente formada por três consoantes) em torno da qual é flexionada com vogais e consoantes complementares para formar substantivos, adjetivos, verbos etc.

Ao nível do mito podemos ainda estabelecer outras suposições ou hipóteses. O livro de Gênesis fala de um outro Enoque, filho de Jerede, cuja ascendência provém de Sete, o terceiro filho de Adão. Este segundo Enoque foi pai de Matusalém, o homem que na Bíblia teve a vida mais longa (969 anos). Sobre este segundo Enoque diz a Bíblia:

Todos os dias de Enoque foram trezentos e sessenta e cinco anos. 
Andou Enoque com Deus, e já não era, porque Deus o tomou para si. $^{\text {b }}$

O relato bíblico "Andou Enoque com Deus, e já não era, porque Deus o tomou para si" era tradicionalmente interpretado com o sentido de que não morrera mas fora transportado em vida para o céu por sua virtude. Muitos livros apocalípticos focalizam sua morte; os primeiros cristãos utilizavam-se do ponto de vista aceito sobre Enoque para explicar a imortalidade de Jesus. Tal argumento provocou reação entre os rabinos, alguns dos quais chegaram a negar a virtude de Enoque. Somente após os cristãos se separarem completamente dos judeus foi que Enoque recuperou a popularidade na doutrina judaica; foi então identificado ao anjo Metraton, e surgiu toda uma literatura mística em torno de sua personalidade. Alguns críticos modernos sustentam que os 365 anos de Enoque correspondem aos 365 dias do calendário babilônico e que a história de Enoque era, originalmente, um mito solar da Babilônia.

Bibliografia Consultada

1. BÍBLIA. Português. Bíblia Sagrada. São Paulo, Paulinas, 1969.

2. ENCICLOPÉDIA Judaica. Rio de Janeiro, Tradição, 1967.

3. FREUD, Sigmund. Totem e Tabu. Rio de Janeiro, Delta, s. d. Escrito em 1913.

4. FROMM, Erich. Análise do Homem. Rio de Janeiro, Zahar, 1963.

5. - . O Espírito da Liberdade. Rio de Janeiro, Zahar, 1967.

6. GAVES, Robert \& PATAI, Raphael. Hebrew myths: the book of genesis. New York, McGraw-Hill, 1966.

7. SCHOLEM, Gershom G. Major trends in jewish mysticism. New York, Schocken, 1954.

\footnotetext{
${ }^{\mathrm{b}}$ GÊNESIS 5: 23-4. In: BÍBLIA. Português. Bíblia Sagrada. São Paulo, Paulinas, 1969. p. 28
}

8. SIMS, Albert E. \& DENT, George. Who's who in the Bible. New York, Philosophical Library, 1960. 
Não me deterei no diagnóstico da América Latina, tarefa que exigiria um trabalho de âmbito maior que este e que já foi realizado com profundidade por diversos autores.

Parto da ideia de que a América Latina, guardadas as diversidades entre os países que a compõem, apresenta-se como um continente que se evidencia por seu atraso em relação a outras áreas. $\mathrm{O}$ quadro geral caracteriza-se por uma predominância econômica das atividades ligadas ao setor primário, frequentemente com hegemonia de um único bem. Má distribuição da renda, baixas oportunidades educacionais e profissionais, falta de mão-de-obra qualificada, índices desfavoráveis no que concerne a saúde, alfabetização, industrialização, etc., são geralmente flagrantes em muitos países latino-americanos.

Um processo que deve ser salientado é a crescente urbanização que vem ocorrendo nestes países. Esta tendência se desenvolve menos em função de uma industrialização, que é apenas incipiente, e mais devido a condições desfavoráveis do meio rural. A cidade é visualizada como uma possibilidade de ascensão social e econômica, que nem sempre ocorre, o que pode ser atestado pelos grupos marginalizados que vivem na maioria das grandes cidades latinoamericanas. Nestas, frequentemente, a taxa de crescimento industrial é inferior à taxa de crescimento urbano, ocasionando desemprego e outros problemas.

Os problemas com que se deparam os países latino-americanos só podem ser enfrentados de um modo global. Atacá-los isoladamente, como se não fossem partes de um todo complexo, provavelmente redundará em fracasso e em desperdício de recursos.

O primeiro passo para a superação do estado em que se encontram países da América Latina é o estabelecimento de um programa de ação, baseado na realidade, e que seja exequível política e economicamente.

Este programa deve partir de um diagnóstico global do país que detecte suas dificuldades, pontos de estrangulamento e suas potencialidades, culminando com uma política que trace prioridades. O estabelecimento de opções por setores aos quais se dará maior 
importância é fundamental, dada a escassez de recursos que impede que se invista em todas as áreas.

A criação de estratégias prioritárias está diretamente vinculada à ideia de mobilizar todos os recursos humanos e materiais disponíveis. Habilidade em abrir novos mercados consumidores no exterior, e na obtenção de financiamentos, empréstimos e auxílios do exterior fazem parte da ideia de utilizar vários meios de propiciar o desenvolvimento.

Dentro deste quadro, duas áreas parecem-me prioritárias: indústria e educação. Estas áreas oferecem ainda a vantagem de poderem capitalizar favoravelmente a tendência irreversível à urbanização.

Entretanto, para que não surjam distorções entre os setores primário e secundário é preciso, simultaneamente, promover uma racionalização da agricultura. É necessário preparar o campo para que com uma população percentualmente cada vez menor possa suprir a cidade. Isto implica numa modernização das formas de produção da pecuária e da lavoura. Esta modernização envolve reforma agrária, uso intensivo do solo, pecuária intensiva, diversificação da produção, produção dos insumos para as indústrias que utilizam matérias-primas do setor primário, introdução de técnicas que aumentem a produtividade da pecuária e da lavoura, etc. As medidas variarão de país para país, levando em conta aspectos políticos e sociais. Uma adequada política no setor primário permitirá desenvolver as duas áreas que mencionei como prioritárias.

As razões que tornam a industrialização uma necessidade imperiosa para os países latino-americanos superarem o subdesenvolvimento foram analisadas pelo economista Raul Prébisch. Demonstrou ele que a deteriorização dos termos de intercâmbio que sofrem os produtos não industrializados em relação aos industrializados faz com que os países latino-americanos necessitem industrializar-se se quiserem desenvolver-se.

Não me parece possível determinar genericamente o que os países da América Latina devem produzir, pois isto variará de país para país, de acordo com os recursos e facilidades para a produção, bem como a existência de mercados consumidores.

A industrialização deve vir acompanhada de uma política consciente de urbanização. Duas tendências precisam ser impedidas. A primeira é a de que a urbanização se dê sob forma atomizada em várias cidades o que acabaria ocasionando que em nenhuma delas houvesse uma suficiente massa crítica de recursos humanos e materiais necessários aos empreendimentos industriais. A segunda tendência a ser evitada é a hipertrofia de apenas um centro urbano, que ficaria cercado de um deserto rural.

Para evitar estas duas tendências negativas pode-se estabelecer, através de estudos de polarização, que cidades têm condições de se constituírem em pólos de desenvolvimento e em função disto canalizar recursos e investir prioritariamente nelas, o que também induzirá uma imigração para as mesmas.

Num país que experimenta um processo de urbanização e industrialização, a educação tem de ser reformulada em suas bases. Dois seriam os objetivos gerais do sistema educacional. $\mathrm{O}$ primeiro consiste em preparar os indivíduos a desempenhar funções que a industrialização exige, capacitando-os profissionalmente. O segundo objetivo é prepará-los a enfrentar e promover as mudanças sociais e tecnológicas que se multiplicarão com o processo urbano-industrial e que por ele serão exigidos.

Para alcançar estes objetivos o sistema educacional deve estruturar-se com a maior flexibilidade possível, a fim de se ajustar a inúmeras necessidades que as transformações constantes do processo urbano-industrial acarretarão. Não há sentido em copiar modelos de países mais adiantados cuja realidade é outra, pois os problemas a serem superados são diferentes.

$\mathrm{O}$ ensino que deve ser buscado é o ensino ligado à tecnologia com vistas à capacitação profissional. $\mathrm{O}$ fato de se abandonar $\mathrm{o}$ ensino retórico e decorativo, e optar por um ensino com aplicação prática, não implica numa desumanização educacional. Este ensino vem acompanhado do desenvolvimento de hábitos e atitudes que 
frisam qualidades compatíveis com a era em que vivemos. O que é suprimido é apenas o bacharelismo.

Do ponto de vista funcional, a capacitação profissional implica em considerar cada nível de ensino como terminal, e não como preparatório a um nível seguinte, pois considerável parte da população de alunos não tem condições de prosseguir os estudos até níveis mais avançados. Por isto os currículos precisam ser construídos com o objetivo de fornecer em cada nível de estudo um conjunto de recursos que permita ao aluno utilizá-lo profissionalmente.

Esta estratégia educacional se reveste de fundamental importância se nos lembrarmos que na maior parte dos países latinoamericanos os jovens representam mais da metade da população. Esta camada populacional está constantemente pressionando o mercado de trabalho, que não consegue criar o número suficiente de empregos por um baixo nível de industrialização e por falta de qualificação profissional dos jovens. Esta estratégia combinada com uma política de industrialização permitiria quebrar o círculo vicioso constituindose num efeito multiplicador, pois ao mesmo tempo em que cria novos empregos, transforma os empregados em consumidores.

Se cada nível de ensino é considerado como terminal é preciso que a qualquer momento o aluno possa voltar aos estudos de acordo com suas necessidades. $\mathrm{O}$ estudo não se daria exclusivamente na escola, mas através de várias outras instituições.

A televisão pode ser usada com bons resultados como meio educacional, as fábricas podem ministrar cursos a seus operários, o exército pode fornecer instrução aos que nele ingressam sem preparo, ao mesmo tempo que utiliza os que tiveram uma formação mais completa como professores. Todos estes estudos teriam validade mediante exames que os aferissem.

Dentro deste sistema educacional, a universidade deve ser uma instituição-chave, essencialmente ligada ao desenvolvimento do país. Isto equivale a considerá-la não como um mero depositário de conhecimentos, mas como um agente de mudança, preocupado na resolução de problemas do país e na criação de soluções que propiciem o desenvolvimento almejado. Neste sentido os centros de pesquisa e de estudo universitários devem desempenhar um papel importante, fornecendo o apoio científico e tecnológico indispensável a um país que inicia um processo de industrialização e desenvolvimento. 